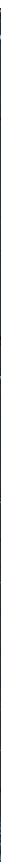

Our bones have evolved over millions of years.

\title{
EVOLUTION
}

\section{The skeleton articulated}

\section{Jan Zalasiewicz enjoys Brian Switek's study on the long journey of the human scaffold.}

\section{$\mathrm{T}$} he bony scaffolding beneath our skin can move us emotionally as well as physically. In enabling our lives, yet enduring beyond them, our skeletons challenge our understanding of ourselves. This premise underpins Brian Switek's Skeleton Keys, a thoughtful, engaging meditation on the origins of the human skeleton, how it functions (or malfunctions) and how we come to terms with our essential but unsettling osseous framework.

Bone's potential for physical immortality reminds us all too vividly of our personal mortality. Switek conveys the Grand Guignol aspects of this with suitably horrified fascination - contemplating, say, the bones of England's King Richard III, hacked and broken in his final hour on the battlefield. Dinosaur bones, however awe-inspiring, cannot chill the spine in quite the same way as the fleshless frames of our own kind.

The emphasis is thus very much on the 'our'. Switek has long enthused, and written elegantly about, the bones of our distant relatives, not least the dinosaurs. And some, such as the monstrous Supersaurus, are touched on in this book. The even more ancient history of the vertebrates is neatly outlined early on, their origins in the Cambrian period exemplified by Pikaia, an extinct eel-like marine organism that had

no skeleton but probably possessed a notochord, the backbone's forerunner. Pikaia was found in the roughly 508-millionyear-old Burgess Shale, a rich trove of fossils discovered in Canada in 1909 by the redoubtable palaeontologist Charles Doolittle Walcott.

The other creatures

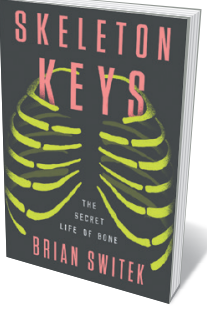

Skeleton Keys: The Secret Life of Bone

BRIAN SWITEK

Riverhead (2019) of the Burgess cornu-

copia - and the many sophisticated, mainly external, skeletons then being conjured up by invertebrate groups such as arthropods - are mentioned only briefly. This is a narrative of bone, not shell, and the early carapace-clad organisms are significant here mainly for effectively pushing the vertebrates to the sidelines for more than 100 million years. The vertebrate skeleton eventually prospered, however, and Switek describes some key steps along the way, such as how it went from being external to internal among early fishes.

Further towards our particular twig of life's tree, dinosaurs make a guest appearance, with legendary nineteenth-century US bone hunters and sworn enemies Edward Drinker Cope and Othniel Charles
Marsh in the spotlight. Obsessively driven, and each burning their way through a family fortune, they unearthed many iconic dinosaurs, such as Triceratops and Diplodocus. There is nothing on their UK counterpart Mary Anning, although she performed comparable palaeontological miracles in extracting ichthyosaurs and plesiosaurs from dangerous Dorset cliffs. This nascent scientific field had formidable female protagonists, too, working against tremendous odds.

\section{CLOSE TO THE BONE}

The next 100 million years, in which mammals flourished, are covered swiftly, to get to the Pleistocene bone bonanza of the La Brea tar deposits in Los Angeles, California. Describing these as the most important fossil site on the planet (that's fighting talk to palaeontologists), Switek focuses on the one set of human bones found among the mammoths and lions and sabre-toothed cats. Dubbed La Brea Woman, her 10,000-year-old remains allow Switek to expound on the physical and chemical intricacies of bone in general and human bones in particular. And it is extraordinary stuff, allowing resilience and strength, and continuous internal remodelling. The skeletons of vertebrates, unlike those of arthropods, do not have to be successively moulted as the animal grows, and 
so can reach vast dimensions - as in the blue whale.

This narrative is neatly done, but the fascination exerted by human bone on human minds lies at the book's heart. With Switek, we visit Neolithic tombs and medieval ossuaries, consider skull cults and muse on the bony personification of Death. The book makes extended explorations of how nineteenth-century anthropologists such as Samuel Morton in Philadelphia, Pennsylvania, used skull measurements to claim the existence of racial differences, a malign legacy that, although long discredited in science, lingers today in apologias for racism. Switek also describes the protracted tug-of-war between scientists and the Native American community around the Columbia River in Washington state over who owns the 9,000-year-old skeleton of the Ancient One, also known as Kennewick Man (D. H. Thomas Nature 531, 302-303; 2016). This is terrain most palaeontologists never navigate; Switek picks through it well.

In the book's coda, the narrative gets up close and personal. Switek considers his own skeleton, and how it might follow those of the dinosaurs into geological immortality. Switek's deep-time focus comes through a little too strongly, I think, in his assertion that it is mainly our skeletons that will be left to tell of

"Bone's
potential
for physical
immortality
reminds us all
too vividly of
our personal
mortality."
our passing. Of the detritus that each of us casually scatters - thousands of ballpoint pens, polyester socks, aluminium cans and so on much is a good deal more decay-resistant than the average cranium or femur. Our bones might be only a small part of our ultimate legacy.

Nevertheless, as this book shows, the skeletal side of life grips us now, and might enthral whoever excavates our remains in the far future. As Switek ponders the sediments in which his own bones might be fossilized, he needs to think of larger geological processes. The sea floor off the shore of New Orleans, Louisiana, might provide a good start: there are stagnant muds, and local tectonic subsidence will allow the fossil to be securely entombed. In the meantime, we should enjoy Switek's talent for spinning compelling tales of old bones. -

Jan Zalasiewicz is professor of palaeobiology at the University of Leicester, UK. With Mark Williams, he is author of Skeletons: The Frame of Life. e-mail:jaz1@leicester.ac.uk
NEUROSCIENCE

\section{Bad science and the unisex brain}

$\mathrm{E}$ arly in The Gendered Brain, cognitive neuroscientist Gina Rippon describes one of the myriad brain studies heralded as 'finally' explaining the difference between men and women. It was a magnetic resonance imaging (MRI) analysis of 21 men and 27 women by researchers at the University of California, Irvine (R. J. Haier et al. NeuroImage 25, 320-327; 2005). Tiny by today's standards, this brief communication nonetheless went on quite a publicity tour, from newspapers and blogs to television, books and, eventually, teacher education and corporate leadership conferences.

I woke one morning in 2010 to see an especially bad extrapolation of this study on the Early Show, a programme on US television network CBS. The presenter, Harry Smith, gushed as medical correspondent Jennifer Ashton declared that men have "six-and-a-half times more grey matter" than women, whereas women have "ten times as much white matter" as men. Next came the obvious quips about men's talent at mathematics and women's uncanny ability to multitask. Never mind that these differences would demand that women's heads were about $50 \%$ larger, or that the Irvine team didn't even compare brain volumes, but investigated a correlation between IQ and measures of grey or white matter.

\section{NEUROSEXISM}

The history of sex-difference research is rife with innumeracy, misinterpretation, publication bias, weak statistical power, inadequate controls and worse. Rippon, a leading voice against the bad neuroscience of sex differences, uncovers so many examples in this ambitious book that she uses a whack-a-mole metaphor to evoke the eternal cycle. A brain study purports to discover a difference between men and women; it is publicized as, 'At last, the truth!', taunting political correctness; other researchers expose some hyped extrapolation or fatal design flaw; and, with luck, the faulty claim fades away - until the next post hoc analysis produces another 'Aha!' moment and the cycle repeats. As Rippon

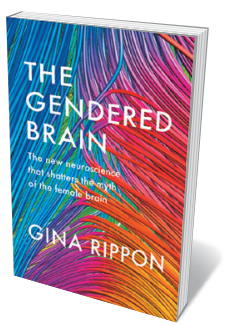

The Gendered Brain: The New Neuroscience That Shatters The Myth Of The Female Brain

GINA RIPPON The Bodley Head (2019)

of female brain - gloated about since the nineteenth century - modern neuroscientists have identified no decisive, category-defining differences between the brains of men and women. In women's brains, language-processing is not spread any more evenly across the hemispheres than it is in men's, as a small 1995 Nature study proclaimed but a large 2008 metaanalysis disproved (B. A. Shaywitz et al. Nature 373, 607-609 (1995) and I. E. Sommer et al. Brain Res. 1206, 76-88; 2008). Brain size increases with body size, and certain features, such as the ratio of grey to white matter or the cross-sectional area of a nerve tract called the corpus callosum, scale slightly non-linearly with brain size. But these are differences in degree, not kind. As Rippon notes, they are also seen when we compare small-headed men to large-headed women, and have no relationship to differences in hobbies or takehome pay.

\section{HISTORY OF BIAS}

Rippon's central message is that "a gendered world will produce a gendered brain". Her book stands with Angela Saini's 2017 Inferior and Cordelia Fine's 2010 Delusions of Gender in rooting out the "neurosexism" that has pervaded attempts to understand difference at the brain level. It's a juicy history that would make for 